\title{
Customer Loyalty: A Gender Based Study of Telephone Sector
}

\author{
Anil K. Singh \\ Associate Professor, IPS College, Gwalior, M.P., India.
}

CITATION: Singh, Anil K. (2019), "Customer Loyalty: A Gender Based Study of Telephone Sector”, MERC Global's International Journal of Management, Vol. 7, Issue 3, pp. 217-221.

ARTICLE HISTORY: Submitted: February 12, 2019, Revision received: March 20, 2019, Accepted: April 05, 2019

ARTICLE TYPE: Research paper

\begin{abstract}
With increasing teledensity, the telecom market has become a mature market and the key to survival has shifted from increasing customer base to retain the existing customers. Companies in the telecom sector are leaving no stone unturned to keep their customers loyal towards them. The goal is always elusive but equally worth pursuing as long term survival is possible only by keeping the customers loyal. Besides focusing on service quality and customer satisfaction which are considered obvious determinants of customer loyalty, telephone companies are keen to understand the construct of customer loyalty in absolute totality. The present study tries to decode the impact of human gender on customer loyalty. Data for the study was collected from mobile subscribers in Gwalior region. The study finds females to be more loyal towards the service providers in comparison to their male counterparts.
\end{abstract}

KEYWORDS: Customer loyalty, Gender, Customers, Teledensity.

\section{REFERENCES}

1. Berry, L. L. and Parasuraman, A. (1992), "Prescription for a service quality revolution in America", Organisational Dynamics, Vol. 13, Issue 4/5, pp. 5-15.

2. Dawes, J. and Swailes, S. (1999), "Retention sans Frontieres: issues for financial service retailers", International Journal of Bank Marketing, Vol. 17, Issue 1, pp. 36-43.

3. Day, G. S. (1969), "A two-dimensional concept of brand loyalty", Journal of Advertising Research, Vol. 9, Issue 3, pp. 29-35.

4. Dick, A. S. and Basu, K. (1994), "Customer loyalty: Toward an integrated conceptual framework", Journal of the Academy of Marketing Science, Vol. 22, Issue 2, pp. 99-113.

5. Fornell, C. (1992), "A national customer satisfaction barometer: The Swedish experience", Journal of Marketing, Vol. 56, Issue 1, pp. 6-21.

6. Foxall, G. R. and Goldsmith, R. E. (1994), Consumer Psychology for Marketing, Routledge London.

7. Garbarino, E. and Johnson, M. S. (1999), "The Different Roles of Satisfaction, Trust and Commitment in Customer Relationships", Journal of Marketing, Vol. 63, Issue 2, pp. 70-87.

8. Gerpott, T. J.; Rams W. and Shindler, A. (2001), "Customer retention, loyalty and satisfaction in the German mobile cellular telecommunication market", Telecommunication Policy, Vol. 25, Issue 4, pp. 249-269.

9. Gremler, D. D. and Brown, S. W. (1996), Service loyalty: its nature, importance, and implications, International Service Quality Association Inc., NewYork.

10. Heskett, J. L. (2002), "Beyond Customer Loyalty”, Managing Service Quality, Vol. 12, Issue 6, pp. 355357.

11. Inieta, M. A. and Sanchez, M.(2002), "Retail Customer Commitment and Service Segmentation", International Review of Retail, Distribution and Customer Research, Vol. 12, Issue 3, pp. 261-279.

12. Jacoby, J. and Chestnut, R. (1978), Brand loyalty: Measurement and management, John Wiley \& Sons, New York.

13. Keller K. L. (1993), "Conceptualising, measuring, and managing customer-based brand equity", The Journal of Marketing, Vol. 57, Issue 1, pp. 1-22.

14. Kotler, P. and Keller, K. L. (2205), Marketing Management, Prentice-Hall, Englewood Cliffs, NJ. 
15. Lee J.; Lee J. and Feick, L. (2001), "The impact of switching costs on the customer satisfaction - loyalty link: Mobile phone service in France", Journal of Services Marketing, Vol. 15, Issue 1, pp. 35-48.

16. Mattila, A. S. (2001), "The Impact of Relationship Type on Customer Loyalty in a Context of Service Failures", Journal of Service Research, Vol. 4, Issue 2, pp. 91-101.

17. Mellens, M.; Dekimpe, M. G. and Steenkemp, J. B. E. B (1996), “A Review of Brand- loyalty Measures in Marketing", Tijdschrift voor Economie en Management", Vol. 41, Issue 4, pp. 507-33.

18. Morgan, Robert M. and Hunt, Shelby D. (1994), "The Commitment- Trust Theory of Relationship Marketing", Journal of Marketing, Vol. 58, Issue 3, pp. 20-38

19. Newman, J. W. and Werbel, R. A. (1973), "Multivariate Analysis of Brand Loyalty for Major Household Appliances", Journal of Marketing Research, Vol.10, Issue 4, pp. 404-409.

20. Nunnally, J. C. (1978), Psychometric Theory, McGraw-Hill, New York.

21. Oliver, R. L. (1999), "Whence customer loyalty?”, Journal of Marketing, Vol. 63, Special Issue, pp. 3344.

22. Oliver, Richard L.; Roland, T. Rust, and Sajeev, Varki (1997), "Customer delight: foundations, findings, and managerial insight”, Journal of Retailing, Vol. 73, Issue 3, pp. 311-336.

23. Reichheld, F. and Sasser, W. E. Jr. (1990), "Zero defections: Quality comes to services", Harvard Business Review, Vol. 68, Issue September/October, pp. 105-11.

24. Reichheld, F. F. (1996), "Learning from customer defections", Harvard Business Review, Vol.74, Issue 2 , pp. 56.

25. Reichheld, F. F. and Schefter, P. (2000), "E-loyalty", Harvard Business Review, Vol. 78, Issue 4, pp. 105-113.

26. Surprenant, C. F. and Solomon, M. R. (1987), "Predictability and personalisation in the service encounter", The Journal of Marketing, pp. 86-96.

27. Zeithaml, V. A., Berry, L. L. and Parasuraman, A. (1996), "The behavioural consequences of service quality", Journal of Marketing, Vol. 60, Issue 2, pp. 31-47. 